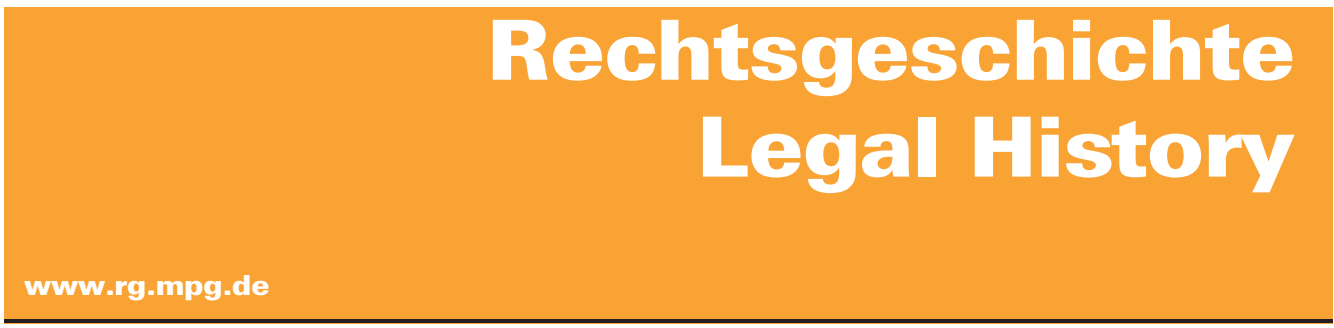

http://www.rg-rechtsgeschichte.de/rg24

$\mathrm{Rg} 22016$

$420-427$

Zitiervorschlag: Rechtsgeschichte - Legal History Rg 24 (2016)

http://dx.doi.org/10.12946/rg24/420-427

\title{
Marianna Muravyeva
}

\section{History of Social Law in Russia}




\section{Marianna Muravyeva}

\section{History of Social Law in Russia}

1 The Emergence of Social law: between Private and Public

In Russia, social law includes social security and social work as two major directions of social legislation, and they are often considered one of the major policy issues because they involve the protection of social and economic rights, the guaranteeing of which is still viewed as a primary function of the state

Art. 7 of the Constitution declares Russia a ssocial state`, where:

the labour and health of people shall be protected, a guaranteed minimum wage shall be established, State support shall be provided for the family, motherhood, fatherhood and childhood, to the disabled and to elderly citizens, the system of social services shall be developed and State pensions, allowances and other social security guarantees shall be established. ${ }^{\mathbf{1}}$

As we see, article 7 outlines the main components of social law: health and labour provisions, minimum wage, state support for the family, protection of the disabled and elderly. Such an attitude is based not only on Soviet heritage, but also on the pre-revolutionary legal focus on the underprivileged and vulnerable groups, which required additional protection from the state and society.

Some Russian scholars tend to trace the origins of social law all the way back to medieval times. This is usually done by scholars who view social law as emerging from the state supported charity work and eventually evolved into social security. According to this position, Prince Vladimir's Church Regulations of 996 - which launched the first hospitals, alms houses and formally separated the jurisdiction between the prince and the Church as well as insisting that the Church should take up the issue of charity by supporting the sick and needy - should be considered the first legal act by the central authorities to establish the state system of social support institutions. ${ }^{2}$ However, such an approach is based on a very particular view of Russian public history as well as a misinterpretation of the relationships between the Church and the prince's powers in the early medieval and medieval periods. More substantiated approaches trace Russian state promoted social support systems to the late 17 th century, when the state established a chain of alms houses for the poor and sick and introduced a formalized list of rules for determining the need for social support, i.e. admission to such houses (disability, inability to work, old age, mental state, etc.). ${ }^{3}$ This tradition was continued by Peter I, who also introduced proto-pensions and other benefits, mostly for the military (especially those disabled in war) and retired officials. It was Catherine II who established the state-sponsored system of social services as part of her administrative reform of 1775 . The newly founded system was once more reformed to create the Department of the Institutions of Empress Maria Fedorovna, which managed the charitable institutions, such as Foundling homes, schools and hospitals, under the patronage of the Royal Family. ${ }^{4}$

Those scholars who see social law and social security law as based on the system of social insurance trace the origins to the law on social insurance offices at the state-owned mining industries of 1861, which introduced benefits for the sick as well as pensions for the disabled, widows and orphans of miners. For them, the period before 1917 was the time when social security was usually a matter of negotiation between the owners of enterprises and their workers, that is, it was optional. This stood in stark contrast to the compulsory security provided by the state at state-owned factories and manufactures. In 1918 the system of state-sponsored social security was introduced by the Bolsheviks; it was based on the principle of sequality for alk, but only provided support for the working class. The 1930s saw the emergence of a depersonalised state support system that financed
1 The Constitution of the Russian Federation (1993), available at: http:// www.constitution.ru/index.htm. Accessed 20.04.2016.
2 Mel'nikov/Kholostova (2005); Gusov et al. (2010).

3 Barlova (2013).

4 LindenMeyer (1996). 
social benefits and pensions through state enterprises and included all Soviet citizens. This system collapsed in 1991 and gave way to the new constantly reforming social security aiming at universal support but which needs to prioritise. ${ }^{5}$ As we will see in this analysis, the shape of the social security system and its legal provisions are heavily dependent on the economic forms Russia has experienced: the move to capitalism, then to socialism and back again to capitalism and market economy. Each of these economic forms changed the life of people, labour and civil law dramatically.

There is a general agreement that the Soviet system of social security provided egalitarian support for all regardless of actual income level and need for such support. As a result, Soviet social law, although an important area of legislation, served as an instrument of power and formal tool of control. With the transition to the market economy, the state had to come up with new social legislation strategies that would provide not only plausible regulation but would also truly protect human rights and guarantee the minimum quality of life provided for in the Russian Constitution. ${ }^{\mathbf{6}}$

\section{What is Social Law?}

There are two approaches to social security highlighting the different aspects of social law: economic and legal. Scholars have been debating the essence, notion and method of social law over the course of the past 80 years. This eventually culminated in a major historic debate that gave rise to the social security law as a separate branch of the Russian legal system in the 1970s and 1980s.

Scholars using the economic approach to social security viewed all types of social services financed through the social consumption funds, including free school education, social housing, leisure activities, and all types of pensions and benefits, as objects of social law regulation. ${ }^{7}$ Those scholars who used the legal approach to social security, used the idea of social justice as their point of departure, that is, that the State and society should protect those who are in actual need of help. In the 1920 s and 1930s, scholars such as Vasilii Dogadov and Nikolai Semashko developed the concept of social risk groups, and these groups should be supported via a justifiable distribution of collective funds. ${ }^{\mathbf{8}}$ They also introduced the notion of "a difficult life situation ", that is, the situation assessed as warranting state sponsored help. However, in their opinion, considering the devastating impact of the Civil War, all Soviet citizens deserved such help. The majority of them also used the term "social insurance" rather than social security, thus underlining that contributions to the collective insurance fund should be made by individuals and enterprises alike. ${ }^{9}$ Due to the specificity of the period, it was the medical profession that started the discussion on social law and social security, thus continuing the pre-revolutionary tradition of treating social services as a task primarily for medical practitioners rather than lawyers. To this end, Natan (Nikolai) Vigdorchik (1874-1954) was a physician and social democrat who practiced in the working class neighborhoods of St. Petersburg. He was particularly involved in the development of social insurance policies for workers and published a great deal on the topic starting in 1909. By the 1920s, he was considered a leading authority on social insurance. $^{10}$

At the time, social law belonged to administrative law and was referred to as the slaw of social culture that included legal provisions on education, health and social security to ensure human development and protection. ${ }^{\mathbf{1 1}}$ Vladislav Durdenevsky's definition laid the foundation for the later discussions on social law and its sphere of regulation. This approach also reflected the social legislation of Stalin's industrialisation that relied on class differentiation. Social security was intended for the working people employed by the state enterprises; in other words, those who were selfemployed and all the peasants were excluded from
5 RoIK (2005); UKhalina (2009).

6 ZaKharov/ TuchKova (2005); Mikhalev (1996); Arhangelsky (1998); Arakcheev (2003).

7 Khabibi (1986); Ivankina (1979).

8 Dogadov (1926); Semashko (1938).

9 VigdorCHIK (1925); DuRDENEVSKY (1929).
10 VIGDORCHIK (1909); VIGDORCHIK

(1912); VIGDORCHIK (1915);

Vigdorchik (1917). See also RetneV

(2004).

11 Durdenevsky (1929) 8-10. 
the benefits of the state support. However, just as prior to the revolution of 1917, the area of law dealing with social security provided assistance to some social groups but not to others. It could even be said that pre-revolutionary legal provisions permitted greater access to social security benefits, even if this access was not based on the concept of social justice and equality as Soviet law and the Soviet Constitution of 1936 implied. $^{\mathbf{1 2}}$

The new discussion on the essence of social law emerged in the 1970s, when the USSR ratified the ICESCR and started its active participation in the ILO. The new pension law of 1954, the law on pension provisions for the collective farm workers of 1964 and the new social insurance law of 1970 stimulated Soviet lawyers to revise the previous approach to social and social security law. Vitaliy Andreev, who started the discussion in the early 1970s, insisted that social law should work closely with social support in order to assist those unable to work and provide for themselves: the elderly, disabled, mothers caring for their children, etc. According to Andreev, the law should, furthermore, include medical and rehabilitation support. ${ }^{13}$ Others did not share his opinion. The representatives of labour law treated sick leave, compensations for industrial accidents and health injuries (including the disabilities resulting of it) as a part of social law. ${ }^{\mathbf{1 4}}$ By the 1990 s, the majority of lawyers agreed that social law should include the regulation of support for social groups in difficult life situations and those unable to work (due to age, health or parenthood). Moreover, it should also include legislation on social protection and guarantees of social rights, such as the right to labour and social benefits. ${ }^{15}$

Russian social law is a fairly young discipline, and for this reason, scholars primarily focus on current issues. The history of social law and social security law is very much in its early stages and does not have a separate historiography to speak of. In the following sections, I will outline existing approaches to various institutions of social law in order to highlight its contemporary understanding and how they are viewed historically.

3 Pensions, Sick Leave and Unemployment: Social Security for (non)Working People

Current Russian legislation includes several types of pensions, most generally, those based on previous working experience and so-called »social pensions", that is, for those people who do not have the right to a regular pension. Working pensions further include pensions based on retirement age (55 for women and 60 for men) and the number of years worked (no less than 15 years), pensions for special categories of workers (officials, the military, judges, etc.) and disability pensions as a result of industrial accidents or health-related injuries. ${ }^{16}$ Pensions for officials and the military were the first types of social insurance in Russia.

The law concerning pensions and allowances from 1827 established the very first regular cash allowances and pensions for officials, including the police. At that time, the category of officials included everyone employed by the state in various capacities, equivalent to public sector employees today and not just civil servants. This gave rise to the military pensions and social support for all state workers, for example, teachers and postmasters. In 1842, the clergy received pension provisions. ${ }^{17}$ The state pension system was quickly supplemented by the social insurance schemes, which were designed to provide social support, including pensions and other types of allowances, for those who were not employed by the state. ${ }^{\mathbf{1 8}}$

By the early 20th century, pension funds were organised throughout the country; these pensions and other employment benefits, such as sick leaves, injury payments and disability benefits, spread into all of the industries, both state-owned and private. With the laws of 1901-1903 and especially 1912, social security and pension provisions were introduced for the working classes, thus laying the
12 FitzPatrick (1993); AraKCHEeV (2003).

13 AndREev (1974).

14 Batygin (1979); Ivanova (1983); KuZMina (1982); ShaikHatdinov (1986); GUSHCHIN (1982).

15 Gusov et al. (2010); ZaKHARov/ Tuchkova (2005); Fetiukhin (1998).
16 Tuchкova (2016).

17 Kulchitskit (2008); Eruslanova et al. (2007).

18 Rafikova (2011). 
foundation for universal pension provisions in the future. ${ }^{19}$ Scholars agree that, although the prerevolutionary system did not cover the majority of the population, that is, peasants, it did manage to provide for all the other social groups. ${ }^{20}$ However, scholars looking at social law focused on the working class, especially those involved in private enterprises, have pointed out that these provisions covered only 20 per cent of all workers in Russia at the time, for the law of 1912 included social provisions only for what they saw as medium-sized and big enterprises (more than 20 employees), which left out a tremendous number of small businesses. In their opinion, this greatly contributed to the revolution of $1917 .{ }^{21}$ And yet another group of scholars tend to praise Russian pre-revolutionary entrepreneurs for being socially-minded. It is stated that their efforts resulted in the organisation of decent working conditions within their companies, including private pension arrangements and other benefits. ${ }^{22}$

With the Bolshevik revolution of 1917 came a significant change in the pension and work benefits situation, for the whole point of the socialist system was to provide universally for all working people. One of the first decrees introduced by the new government was the Decree on Social Insurance that provided a wide range of benefits for all working people and paupers, which shifted the responsibility of providing funds for these benefits to the businesses. Further legislation in the 1920s, especially during the NEP period, based social benefits on the social insurance principles, while officials and the military were paid by the State, thus continuing the pre-revolutionary tradition. It was Stalin's policies that provided almost universal coverage for working people and public sector employees; however, the peasantry continued to be excluded from the pension support. Scholars note that the usage of social insurance, instead of the state support, was the only real possibility for the socialist economy at the time. Since the economic system was devastated after the Revolution and Civil War, the state was not in a position to provide anything. With the development of the planned economy - when all of the businesses ended up being state-owned and private businesses were made illegal - the State began supplementing social insurance with the budgetary provisions, thus providing the working people with a minimum of social support. ${ }^{23}$

By the 1960s, when the USSR ratified the ICESCR, the State made social support and social security its primary policy concern. It wanted to show both its own citizens and the entire world that the Soviet system cared about people and better provided for them compared to the capitalist countries. The State Social Insurance Fund was organised to guarantee the social and economic rights of all Soviet citizens, and it included pensions, employment related benefits (such as sick leave, injury coverage, disabilities, etc.). Once this system came under the complete control of the state, it led to the emergence of paternalist socialism, where the State became the sole source of social benefits and payments. Scholars point out that while this situation brought about the most accessible system of social benefits, they were quite low and ensured the very minimum of social and economic support, that is, making everyone equal in being poor. ${ }^{24}$

Understanding the Soviet social security law was of essential importance for policy and lawmakers during the 1990s, when they tried to adapt to the market economy and reform the system in according to the newly emerged social and economic conditions. The entire focus of scholarship, at the time, concentrated on finding possible models that had proven successful either in Russia's historical past or in other countries. This triggered a number of studies lacking in any deep analytical approach: the goal was to find out how the system worked, to describe it and let others draw their own conclusions. 
4 Welfare State and Social Justice: Did it Really Work?

While pension and work benefits have been evolving in connection with industrial policies and the needs of the State to bring forward a certain economic system, market economy or planned economy, social benefits emerged to solve two problems. The first one was connected with demography and targeted the population increase, that is, contributed to pro-natalist policies. The second problem dealt with social justice to ensure that everyone feels rewarded for their contribution to social development.

Scholars treat social benefit policies, that is, providing maternity and paternity leave, child benefits, in-kind facilities and privileges for large families (more than three children in Russia), as an important element of social law and the welfare state that Russia claims to be. Family support and family benefits are still considered to be one of the major achievements of the socialist system that allowed women to combine work and child-rearing duties as early as the 1930s. The research on family benefits has been closely connected with the notions of welfare, gender equality and women's rights, so that both Soviet and post-Soviet Russian scholarship has concentrated on gender analysis of the family protection and support system. Scholars have come up with the notions of the paternalist state and gender contract, which allowed Soviet women to experience a double burden: full-time employment and child-rearing duties, not to mention the additional housework responsibilities. ${ }^{25}$ Emancipation of women and changing nature of the family during the 1920s and the 1930s were an essential element of building the socialist economic system, especially the country's industrialisation. Therefore, all of the child-benefits as well as maternity leave and in-kind help (such as milk kitchen, nurseries at the factories, etc.) were designed to free women to work but also to ensure they contributed to the demographic development of the nation. ${ }^{26}$
However, only sociologists and gender historians have provided gender-sensitive analyses of social law in relation to family support. Legal scholars have been exceptionally gender-blind while reporting the successes of Soviet policies and failures of the post-Soviet system. In their view, this type of legislation just reflected the necessity of supporting the family as a production unit. ${ }^{27}$ In fact, they continued the Soviet tradition of a formal attitude toward legal provisions as being a fair and impartial reflection of the social needs. ${ }^{28}$ This is above all visible in relation to social justice issues: legal scholars do not look at family benefits from the perspective of social justice, yet ignore the basic Russian labour law principle to ensure that every employed person has a right to labour and social protection based on it. Ironically, the concept of social justice provided a foundation for socialist law and, in particular, social security law in the USSR, because it was based on the notion of proportionality of the individual contribution to the social development and the reward for it. ${ }^{29}$

Therefore, the assessment of the welfare system was often based on the formal indicators of how much money in benefits was paid to the families and individuals that provided an impressive number. However, as gender researchers noted, the welfare system did not really work in the sense that it did not emancipate Soviet women - on the contrary, it further enslaved them. ${ }^{30}$ With the collapse of the Soviet Union, women were the ones who experienced the entire spectrum of social injustice, because private business saw them as a rather expensive workforce: paying maternity leave, numerous sick leaves to care for the children, and child benefits were things they did not see as profitable. It was up to State to ensure social protection and restore social justice, which the state gradually achieved via strict labour legislation and protection of socio-economic rights legislation. $^{31}$

25 Temkina/RotKirch (2002).

26 Clements (1989); Goldman (1993).

27 Muravyeva (2014).

28 Nechaeva (1988); Afanasieva (2010).

29 Mal'tsev (1977); Musin (1991).

30 Cook (1993).

31 Teplova (2007); Cook (2013). 
5 Conclusion: Gaps in Research and Future Perspectives

Present-day Russian scholarship lacks the foundational and elementary works in social law due to the discipline's young state and its continued emergence. Another reason for the underdevelopment of social law research is its connection with pending practical issues in need of quick solutions. The majority of the research is being carried out by historians, including social historians, whose primary goal is to analyse social law within its particular context, given a particular space and time, without connecting its development to such issues as social justice or state formation or economic system. This accounts for the peripheral standing of such research even within social history. The problem confronting legal scholarship is the need for providing the background for contemporary developments in social law. Yet, many of those scholars do not highlight any (dis)continuities, but rather use the previous legislation and reforms as a mere illustration for the present-day initiatives. Moreover, social research, historical analysis and legal research continue to be separated by the disciplinary boundaries that prevent interdisciplinary approaches to social law.

Nevertheless, there is a positive trend in young scholars taking deep interest in social law, which is evident in the number of dissertations focusing on pensions, social security, labour remuneration and social insurance, defended every year at Russian universities. These dissertations could all potentially become books, and such a development would open up and make this archival research and new scholarship available to the broader academic community and, probably, policy makers, so that their work will benefit from this information.

\section{Bibliography}

- Afanasieva, Liudmila (2010), Okhrana materinstva i detstva na Dal'nem Vostoke v 20-30-kh godakh XX veka [The protection of motherhood and childhood at the Far East in the 1920s and 1930s], Komsomolsk-na-Amure

- Andreev, Vitaliy (1974), Pravo sotsial'nogo obespecheniia v SSSR [The law of social security in the USSR], Moscow

- Arakcheev, Victor (2003), Istoriia zakonodatel'stva i prava Rossii o sotsial'nom obespechenii [The history and law of social security in Russia], in: Vestnik Tomskogo gosudarstvennogo universiteta 279, 18-26

- Arhangelsky, Vitaly D. (1998), Modern Russian social security, in: Social Service Review 72, 2, 251-268

- Ashmarina, Svetrana (2012), Sotsial'noe strakhovanie na Urale, 1903-1914 [Social insurance in the Urals region, 1903-1914], Moscow

- Astrakhan, Evgenir (1971), Razvitie zakonodatel'stva o pensiiakh rabochim i sluzhashchim: istoricheskii ocherk (1917-1970) [The development of pension legislation for workers and public sector employees: historical overview (1917-1970)], Moscow

- Axelsson, Runo (2002), Institutional developments in the Russian system of social security: organizational and interorganizational aspects, in: Social Policy \& Administration 36, 2, 142-155

- Barlova, Julia (2013), »Treat them according to the European tradition«: the discourse of blaming the poor, the problem of professional beggars and attitudes to poverty in modern Russia, in: Rowbotham, Judith, Marianna Muravyeva, David Nash (eds.), Shame, Blame and Culpability. Crime and violence in the modern state, London and New York: Routledge, 152-167

- Batygin, Konstantin (1979), Razvitie osnovnykh form sotsial'nogo obespecheniia v svete novoi Konstitutsii [The development of social security law in the aftermath of the new Constitution], in: Sovetskoe gosudarstvo i pravo 3, 19-23

- Chapman, Janet G. (1963), Real wages in Soviet Russia since 1928, Cambridge, Mass

- Clements, Barbara (1989), The Birth of the New Soviet Woman, in: Gleason, A. (ed.), Bolshevik Culture, Bloomington: Indiana University Press

- Cook, Linda J. (1993), The Soviet social contract and why it failed: welfare policy and workers' politics from Brezhnev to Yeltsin, Cambridge, Mass

- Cook, Linda J. (2013), Postcommunist welfare states: Reform politics in Russia and Eastern Europe. Ithaca, NY

- Dedul Alexander (1985), Soziale Versicherung in der UdSSR, Moscow

- Dobrokhotova, Elena (1992), Sovetskoe pravo sotsial'nogo obespecheniia [The Soviet law of social security], St. Petersburg

- Dogadov, Vasilir (1926), Sotsial'noe strakhovanie [Social insurance], Moscow

- Durdenevsky, Vsevolod (1929), Lektsii po pravu sotsial'noi kultury [Lectures on the law of social culture], Moscow, Leningrad

- Eruslanova, Raisa, Fedosita Emel'ianova, R. Kondratieva (2007), Pensionnoe obespechenie v Rosii [Pensions in Russia], Moscow

- Fetiukhin, Mikhail (1998), Sotsial'noe pravo [Social law], Volgograd

- Fitzpatrick, Sheila (1993), Ascribing class: The construction of social identity in Soviet Russia, in: The Journal of Modern History $65,4,745-770$ 
- Gumeniuk, Alexey (2013), Sotsial'nye preobrazovaniia v Rossii v 1921-1928 godakh [Social reforms in Russia in 1921-1928], in: Izvestiia Saratovskogo universiteta. Seriia: Isoriia, Mezhdunarodnye otnosheniia 3, 91-100

- Goldman, Wendy Z. (1993), Women, the State and Revolution: Soviet family policy and social life, 1917-1936, Cambridge

- Gushchin, Ivan (1982), Sovetskoe pravo sotsial'nogo obespecheniia: voprosy teorii [The Soviet law of social security: theoretical approach], Moscow

- Gusov, Kantemir, Marina Buianova et al. (2010), Pravo sotsial'nogo obespecheniia [Social Security Law], Moscow

- Ivankina, Tatiana (1979), Problemy pravovogo regulirovaniia raspredeleniia obshchestvennykh fondov potrebleniia [The attitudes to legal regulation of the social consumption funds distribution], Leningrad

- Ivanova, Galina (2013), Formirovanie sovetskoi modeli pensionnogo obespecheniia v seredine 1950-kh gg. [The formation of the Soviet pension model in the mid-1950s], in: Izvestiia Samarskogo nauchnogo tsentra RAN 5, 1, 129-136

- Ivanova, Rosalia (1983), Predmet i metod sovetskogo prava sotsial'nogo obespecheniia [The subject and method of the Soviet law of social security], Moscow

- Kay, Rebecca (2011), Social security, care and the "withdrawing state« in rural Russia, in: Jäppinen, Maija, Meri Kulmala, Aino SaArinen (eds.), Gazing at Welfare, Gender and Agency in Post-socialist Countries, Cambridge: Cambridge Scholars Publishing, 145-169

- Khabibi, Renat (1986), Mekhanizm raspredeleniia obshchestvennykh fondov pri sotsializme [The method of distribution of social consumption funds under socialism], Moscow

- Kulchitski, A.V. (2008), Istoriia pensionnogo obespecheniia rossiian: 1827-1917 [The History of pension provisions in Russia: 1827-1917], in: Izvestiia Rossiiskogo gosudarstvennogo pedagogicheskogo universiteta im. Gertsena 76, 1, 199-204

- Kuprianova, Liubov (1996), Rossiiskie predprinimateli i problemy sotsial'nogo strakhovaniia 1880-1905 [Russian entrepreneurs and social insurance issues 1880-1905], in: Otechestvennaia istoriia 5, 50-65

- Kutsenko, Viktor (1996), Pensionnoe obespechenie v Rossii: istoriia, sostoianie, perspektivy [Pensions in Russia: history, current state, perspectives], Novosibirsk

- Kuzmina, Tamara (1982), Sovetskoe pravo sotsial'nogo obespecheniia [The Soviet law of social security], Saratov

- Levshuk, Mikhail (2011), Stanovlenie pravovoi sistemy dorevolutsionnogo gosudarstvennogo pensionnogo obespecheniia [The emergence of the legal system of pre-revolutionary state pensions], in: Nauchnye vedomosti BelGU. Seriia: Filosofiia, Sotsiologiia, Pravo 14 (109), 125-138

- Lindenmeyer, Adele (1996), Poverty is Not a Vice: Charity, Society and the State in Imperial Russia, Princeton

- Lykova, Lidia. P. (1974), Social security, Moscow

- Mal'tsev, Gennady (1977), Sotsial'naia spravedlivost' i pravo [Social justice and law], Moscow

- McAuley, Alastair (1979), Economic welfare in the Soviet Union: poverty, living standards, and inequality, Madison

- Mel'nikov, Viktor, Evdokiıa Kholostova (2005), Istoriia sotsial'noi raboty [History of social work], Moscow

- Mikhalev, Vladimir (1996), Social security in Russia under economic transformation, in: Europe-Asia Studies 48, 1, 5-25

- Muravyeva, Marianna (2014), Traditional Values and Modern Families: Legal Understanding of Tradition and Modernity in Contemporary Russia, in: Journal of Social Policy Research 12, 4, 625-638

- Musin, Marat (1991), Sotsial'naia zashchita i sotsial'naia spravedlivost' v usloviiakh perekhoda k rynochnoi ekonomike [Social security and social justice in the transformation to the market economy], Kaliningrad

- Nechaeva, Alexandra (1988), Okhrana materinstva i detstva v SSSR [The protection of motherhood and childhood in the USSR], Moscow

- Pudovkin, Alexey (2015), Analiz sistemy pensionnogo obespecheniia v SSSR [The analysis of the pension system in the USSR], in: Vestnik MGIMO 2 (41), 217-223

- Rafikova, Raikhana (2011), Opyt pravovogo regulirovaniia negosudarstvennogo pensionnogo strakhovaniia v dorevolutsionnoi Rossii [The legal regulation of private retirement issuance in pre-revolutionary Russia], in: Vestnik Volzhskogo universiteta im. V. N. Tatishcheva $75,20-30$

- Retnev, Vladimir (2004), N. A. Vigdorchik: kratkii ocherk zhizni, nauchno-obshchestvennoi i pedagogicheskoi deiatel'nosti. K 130-letiiu so dnia rozhdeniia [N. A. Vigdorchik: his short biography, academic, public and pedagogical achievements], St. Petersburg

- Rimlinger, Gaston V. (1971), Welfare policy and industrialization in Europe, America and Russia, New York

- Roik, VAlentin (2005), Evolutsiia form sotsial'noi zashchity v Rossii [The evolution of the social security methods in Russia], in: Strakhovoe delo 1, 41-49

- Semashro, Nikolai (1938), Pravo na sotsial'noe obespechenie [The right to social security], Moscow

- Shaikhatdinov, Vladimir (1986), Teoreticheskie problemy sovetskogo prava sotsial'nogo obespecheniia [Theoretical issues in the Soviet law of social security], Sverdlovsk

- Sivakova, Irina (2015), Pensionnoe zakonodatel'stvo Rossii v Sovetskii period (oktiabr 1917-1928) [Pension legislation in Russia during the Soviet period (October 1917-1928)], Moscow

- Temkina, Anna, Anna Rotkirch (2002), Sovetskie gendernye kontrakty i ikh transformatsiia v sovremennoi Rossii [Soviet gender contracts and their transformation in contemporary Russia], in: Sotsis 11, 4-15

- Teplova, Tatyana (2007), Welfare state transformation, childcare, and women's work in Russia, in: Social Politics: International Studies in Gender, State \& Society 14, 3, 284-322

- Tuchkova, Elvira (ed.), Pravo sotsial'nogo obespecheniia Rossii [The law of social security in Russia], Moscow: Prospekt

- Ukhalina, I. (2009), Evolutsiia instituta sotsial'nogo strakhovaniia i ego stanovlenie v Rossii [The evolution of the institute of social security and its establishment in Russia], in: Terra Economicus 7, 2, 51-54

- Vigdorchik, Nikolai (1925), Teoriia i praktika sotsial'nogo strakhovaniia [Theory and practice of social insurance], Moscow

- Vigdorchik, Nikolai (1917), Gosudarstvennoe obespechenie trudiashchikhsia [State provisions for the working class], Petrodrad 
Forum forum

- Vigdorchik, Nikolai (1915), Strakhovanie ot neschastnykh sluchaev v Rossii [Insurance for industrial accidents in Russia], Petrodrad

- Vigdorchik, Nikolai (1912), Sotsial'noe strakhovanie [Social insurance], St. Petersburg

- Zakharov, Mikhail, Elvira Tuchkova (2005), Pravo sotsial'nogo obespecheniia [Social Security Law], Moscow 